\title{
Extended Spectrum Beta- Lactamase- Producing Uropathogenic Escherichia coli in Pregnant Women Diagnosed With Urinary Tract Infections in South-Western Nigeria
}

\author{
Oluduro Anthonia Olufunke ${ }^{1}$, Aregbesola Oladipupo Abiodun ${ }^{1} \&$ Fashina Christina Dunah $^{1}$ \\ ${ }^{1}$ Department of Microbiology, Faculty of Science, Obafemi Awolowo University, Ile-Ife 220005, Nigeria \\ Correspondence: Oluduro Anthonia Olufunke, Department of Microbiology, Faculty of Science, Obafemi \\ Awolowo University, Ile-Ife 220005, Nigeria, Tel: 234-806-937-9885. E-mail: aoluduro2003@yahoo.co.uk
}

Received: August 14, 2014 Accepted: August 25, 2014 Online Published: September 22, 2014

doi:10.5539/jmbr.v4n1p34 URL: http://dx.doi.org/10.5539/jmbr.v4n1p34

\begin{abstract}
Extended spectrum beta-lactamase (ESBL)-producing uropathogenic Escherichia coli (UPEC) in symptomatic pregnant women with confirmed urinary tract infections in Southwest. Nigeria was reported. Susceptibility of UPEC isolates to $\beta$-lactam and other classes of antibiotics was determined by the Kirby-Bauer's disc diffusion method on Mueller-Hinton agar plate. Detection of plasmid DNA in multiple antibiotic resistant isolates was carried out by alkali lysis (TENS) method. Extended-spectrum- $\beta$-lactamase (ESBL) production was determined by double disk synergy test (DDST). Isolates that were positive to ESBL were mated with non-ESBL- producing $E$. coli and other enterics in a conjugation experiment. Transfer of ESBL-enzyme and other resistance phenotypes in the transconjugants was investigated by DDST. Data obtained were statistically analyzed using SPSS 17 . Greater percentage of the isolates were multiple antibiotic resistant (MAR). Sixty-nine (26.1\%) of UPEC were ESBL producers. Some of the ESBL producers transferred ESBL- enzyme and other resistance determinants to the recipients. Large size plasmid DNA of molecular weight (23.13-33.04 kb) was detected in some representative MAR isolates.
\end{abstract}

Keywords: ESBL, UPEC, pregnant women, UTI, multiple antibiotic resistance

\section{Introduction}

Escherichia coli have been reported to be common causes of hospital acquired infections which can have severe clinical implications with corresponding multiple antibiotic resistance (Aibinu et al., 2002). Extended spectrum $\beta$-lactamases $(E S B L s)$ are plasmid mediated enzymes that confer resistance to penicillin, third generation cephalosporins and aztreonam but are inhibited by clavulanic acid (Paterson and Bonomo, 2005). In Africa, ESBLs-producing bacteria have been reported in Egypt, Morocco, Tunisia, Senegal and South Africa (Bloomberg et al., 2005).

Extended-spectrum $\beta$-lactamase (ESBL)-producing enterobacteriaceae have become widespread in hospitals and are increasing in community settings where they cause a variety of infections. In addition to hydrolyzing most $\beta$-lactam agents, bacteria harboring these enzymes display resistance to other unrelated antimicrobial agents and thus often pose a therapeutic dilemma (Maina et al., 2013). Increase in ESBL-producing enteric Gram-negative bacteria has led to the choice of inappropriate therapy; as a result, the rate of resistance has increased. Antibiotic therapy of infections due to ESBL-producing pathogens is still a clinical challenge. In most cases, carbapenems and fluoroquinolones have been used (Ramphal \& Ambrose, 2006).

Horizontal gene transfer by plasmid exchange between E. coli strains is a recognized source of rapid spread of antimicrobial resistance phenotypes (Fang et al., 2006). The significance of plasmids in disseminating antimicrobial resistance genes is further enhanced by the association of plasmids with mobile genetic elements, such as transposons, integrons and insertion elements (Pitout et al., 2007). Resistance to third generation cephalosporins, ciprofloxacin, trimethoprim-sulfamethoxazole, gentamicin and amikacin was detected in the ESBL- producer group. Selective pressure of the antimicrobials selects those strains that are resistant to the applied antimicrobials causing the resistant strains to multiply and spread. In the last decade, CTX-M enzymes have replaced TEM and SHV mutants as the most prevalent ESBLs worldwide, with E. coli being the major host (Livermore et al., 2007; Paterson \& Bonomo, 2005). Extended spectrum beta-lactamases production have been 
reported among E. coli in both hospital and community settings ((Pitout et al., 2007)). They have also been detected in pets and farm animals, products of the food chain and sewage (Warren et al., 2008). The resistance rate of $E$. coli to third generation cephalosporins ( $3 \mathrm{GCs}$ ) is a broad indicator of the occurrence of ESBLs. It has been discovered that, travellers to countries with high rates of ESBLPCs (e.g. Egypt, India, etc) readily acquire asymptomatic faecal carriage.

Extended spectrum $\beta$-lactamase-producing $E$. coli and other enterobacteriaceae, particularly those producing CTX-M, have spread rapidly among humans and there is evidence of spread among animal populations. Factors that influence the spread of resistance genes as well as resistant bacteria include, antimicrobial usage, co-selection for resistance genes

A number of risk factors of acquiring ESBL-producing bacteria have been identified in hospitalized patients, most of which also apply to other multi-resistant Gram-negative bacilli. These risk factors include: prolonged hospital stay; prior hospitalization; previous use of $3 \mathrm{GCs}$, aminoglycosides and quinolones; presence of medical devices such as urinary catheters and mechanical ventilation (Rodriguez-Bano et al., 2006). In the case of community acquired ESBL infections, older age, female gender, recurrent UTIs/prior invasive procedures (e.g. catheterisation), known faecal carriage, contact with healthcare facilities/residents in care homes and previous antimicrobial treatment are the risk factors (Moor et al., 2008).

Travellers to areas of the world such as India where very high rates of ESBL are present, have been noted to become readily colonized, asymptomatically, with CTX-M-producing ESBL strains (Tham et al., 2010). The present study reports the prevalence of ESBL- producing UPEC in pregnant women with confirmed UTIs in Ondo and Ekiti States, south-western Nigeria.

\section{Methodology}

\subsection{Study Design and Sample Collection}

The study population include symptomatic UTIs pregnant women in Ekiti and Ondo States, South-western Nigeria. Ekiti State is located between longitudes $40^{\circ} 51^{\prime}$ and $50^{\circ} 451^{\prime}$ east of the Greenwich meridian and latitudes $70^{\circ} 151^{\prime}$ and $80^{\circ} 51^{\prime}$ north of the Equator while Ondo State lies between longitudes 4"30" and 6" East of the Greenwich Meridian, 5" 45" and 8" 15" North of the equators

The preliminary identification of E. coli recovered from 400 voided mid-stream urine samples of symptomatic pregnant women with confirmed cases of UTIs was based on colonial morphology by a characteristic green metallic sheen on EMB agar (Oxoid Ltd., Hampshire, England) plate. The identity of isolate was confirmed by various conventional biochemical tests with reference to Bergey's Manual of Determinative Bacteriology (Holt et al., 1994).

\subsection{Antibiotic Susceptibility Testing}

Antibiotic susceptibility testing of isolate was performed by Kirby-Bauer's disc diffusion method. The antibiotics tested and their concentrations ( $\mu \mathrm{g})$ include; cefadroxil (30), ampicillin (10), nalidixic acid (30), cefepime (30), augumentin (30), cefuroxime (30), ceftazidime (30), cefotaxime (30) (Oxoid, Basingstoke, Hampshire, UK); amoxicillin (30), gentamicin (10), ofloxacin (5), ciprofloxacin (30), tetracycline (25), augmentin (30), ceftriazole (30), nitrofurantoin (300), cotrimoxazole (30), and pefloxacin (Fondos, Nigeria). The standardized inoculum (0.5 McFarland Barium Sulphate turbidity standard- $10^{6} \mathrm{CFU} / \mathrm{ml}$ ) was seeded on Mueller-Hinton Agar (MHA) (Hi Media, Vadhani, India) plates. The antibiotic disks were firmly placed on the sterile MHA plates (Oxoid, England) and incubated at $37^{\circ} \mathrm{C}$ for $24 \mathrm{~h}$. Diameter of zones of inhibition was measured to the nearest millimeter using a transparent calibrated ruler and compared to the Clinical and Laboratory Standards Institute (2012). Escherichia coli ATCC 25922 was used as reference.

\subsection{Detection of $\beta$-lactamase Enzymes Producing E. coli}

Extended spectrum $\beta$-lactamase production among the isolates was detected following the double-disk synergy technique (DDST) (Clinical and Laboratory Standards Institute (CLSI), 2012). The standardized isolates were subjected to double-disk synergy tests (DDST) on sterile Mueller Hinton agar plates. Escherichia coli ATCC 25922 was used as reference. The test was performed by placing ceftazidime $(30 \mu \mathrm{g})$ and cefotaxime $(30 \mu \mathrm{g})$ at $20 \mathrm{~mm}$ (center to center) from a centre disk containing augmentin $(30 \mu \mathrm{g})$ (amoxicillin $(20 \mu \mathrm{g})$ plus clavulanate $(10 \mu \mathrm{g})$. Enhancement or potentiation in the zone of inhibition of any of the antibiotic disks toward the center disk containing clavulanic acid indicates the presence of ESBLs (Clinical and Laboratory Standards Institute (CLSI), 2012).

\subsection{In Vitro Conjugation Experiment}

Minimum inhibitory concentrations of the antibiotics (augmentin, amoxicillin, cefadroxil, Cefotaxime, cefepime, ceftazidime, cefuroxime, alidixicAcid, ciprofloxacin, ofloxacin, pefloxacin, gentamicin, tetracycline, 
cotrimoxazole) used in the conjugation experiments were determined by agar dilution method as prescribed by CLSI.[6] Conjugation experiment was performed by the mating assay using the method of Aibinu et al. (2003) in tryptic soy broth for six of the ESBL-producing E. coli isolates as donors and non- ESBL-producing E. coli ATCC 25922 and other enterobacteriaceae (Klebsiella sp, Proteus sp., Salmonella sp. and Shigella sp) as recipients. The donors were tested and confirmed to be sensitive to the antibiotic resistance markers on MHA plates. A suspension of each organism was made in the sterile double strength nutrient broth at $37^{\circ} \mathrm{C}$ and adjusted to $0.5 \mathrm{McF}$ arland Standard. The donor and the recipient were then mixed in a ratio 1:9 (50 $\mu \mathrm{l}$ of the donor to $450 \mu \mathrm{l}$ of the recipient) and incubated at room temperature for $3 \mathrm{~h}$ for conjugation to take place.

One milliliter of each conjugated samples was serially diluted (10-folds) and $0.1 \mathrm{ml}$ from $10^{-3}$ and $10^{-4}$ dilution fractions was spread inoculated onto the surface MacConkey, eosin methylene blue agar and Salmonella-Shigella agar plates supplemented with appropriate minimum inhibitory concentration of antibiotics used as the recipients' markers. Transfer of resistance was read by observation of recovery of the recipient colonies on the agar plates containing the corresponding antibiotics. The transconjugants were subjected to DDST to confirm the transfer of ESBL enzymes and co-transfer of other resistance determinants present in the donor isolates.

\subsection{Plasmid Profiling}

Plasmid DNA extraction of selected multiple antibiotic resistant ESBL-producing isolates was performed using the alkaline lysis 'TENS' (Tris $25 \mathrm{mM}$, EDTA $10 \mathrm{mM}, 0.1 \mathrm{~N} \mathrm{NaOH}$ and $0.5 \%$ SDS- all Sigma products) method of Kraft et al. (1988) and Lech et al. (1987). The extracted plasmid DNA was separated on 0.8\% agarose gel (Oxoid, Basingstoke, England) in a 20-40 $\mu$ l of TE (Tris-EDTA) buffer and a 100 bp ladder (Promega, Madison, USA) was used as standard. The electrophoretic products were viewed using ultraviolet trans-illuminator and the plasmid size was compared to the reference marker.

\subsection{Statistical Analysis}

Significant differences and relationship between the prevalence of ESBL- producing UPEC strains in pregnant women in the study areas were compared using analysis of variance (SPSS 17 version). A value of $p<0.05$ was set as significant

\section{Results}

Table 1. Prevalence of antibiotic resistance among ESBL-producing uropathogenic E. coli in pregnant women with UTI in Ondo and Ekiti States

\begin{tabular}{|c|c|c|c|c|c|c|c|}
\hline \multicolumn{2}{|c|}{ Antibiotics tested } & \multicolumn{6}{|c|}{$\%$ Resistance of the (MAR) isolates $(n=264)$} \\
\hline \multirow[b]{2}{*}{ Classes of antibiotics tested } & \multirow[b]{2}{*}{ Specific antibiotics tested } & \multicolumn{3}{|c|}{$\operatorname{ESBL}(\%)(n=69)$} & \multicolumn{3}{|c|}{ Non ESBL $(\%)(n=195)$} \\
\hline & & Ondo & Ekiti & Total (\%) & Ondo & Ekiti & Total (\%) \\
\hline \multirow[t]{9}{*}{$\beta$-Lactams } & Augmentin & 34 & 30 & $64(92.8)$ & 57 & 57 & $114(58.5)$ \\
\hline & Amoxicillin & 33 & 31 & $64(92.8)$ & 57 & 68 & $125(64.1)$ \\
\hline & Ampicillin & 35 & 33 & $68(98.6)$ & 75 & 77 & $152(77.9)$ \\
\hline & Ceftriaxone & 30 & 32 & $62(89.6)$ & 79 & 87 & $166(85.1)$ \\
\hline & Cefadroxil & 36 & 32 & $68(98.6)$ & 93 & 93 & $186(95.4)$ \\
\hline & Cefotaxime & 31 & 29 & $60(87.0)$ & 54 & 66 & $120(61.5)$ \\
\hline & Cefepime & 14 & 20 & $34(49.3)$ & 16 & 26 & $42(21.5)$ \\
\hline & Ceftazidime & 36 & 31 & $67(97.1)$ & 92 & 92 & $184(94.4)$ \\
\hline & Cefuroxime & 34 & 33 & $67(97.1)$ & 87 & 88 & $175(89.7)$ \\
\hline \multirow[t]{4}{*}{ Quinolones } & Nalidixic acid & 28 & 28 & $56(81.2)$ & 57 & 65 & $122(62.6)$ \\
\hline & Ciprofloxacin & 28 & 24 & $52(75.4)$ & 50 & 66 & $116(59.5)$ \\
\hline & Ofloxacin & 28 & 22 & $50(72.5)$ & 50 & 58 & $108(55.4)$ \\
\hline & Pefloxacin & 34 & 30 & $64(92.8)$ & 60 & 71 & $131(67.2)$ \\
\hline Aminoglycosides & Gentamicin & 28 & 30 & $58(84.1)$ & 34 & 72 & $106(54.4)$ \\
\hline Nitrofurantoins & Nitrofurantoin & 31 & 27 & $58(84.1)$ & 58 & 68 & $126(64.6)$ \\
\hline Tetracyclines & Tetracycline & 36 & 33 & $69(100)$ & 90 & 91 & $181(92.8)$ \\
\hline Sulphonamides/Trimethroprim & Cotrimoxazole & 32 & 32 & $64(92.8)$ & 68 & 88 & $156(80.0)$ \\
\hline
\end{tabular}

Key: MAR $=$ Multiple antibiotic resistant; $\mathrm{ESBL}=$ Extended spectrum $\beta$-lactamase. 
Table 2. Multiple antibiotic resistance (MAR) among ESBL-producing uropathogenic E. coli in pregnant women with UTIs in Ondo and Ekiti States

\begin{tabular}{cccccc}
\hline \multirow{2}{*}{ Number of classes of antibiotics tested } & \multicolumn{2}{c}{ ESBL producer $(\mathrm{n}=69)$} & \multirow{2}{*}{ Total } & Percentage (\%) \\
\cline { 2 - 5 } & Ondo State & Ekiti State & & \\
\hline 6 & 15 & 21 & 36 & 52.2 \\
5 & 10 & 8 & 18 & 26.1 \\
4 & 7 & 4 & 11 & 15.9 \\
\hline
\end{tabular}

Key: MAR = Multiple antibiotic resistant; ESBL= Extended spectrum $\beta$-lactamase.

Table 1 shows the prevalence of antibiotic resistance among ESBL- producing UPEC isolates in Ondo and Ekiti States. Sixty-nine $(26.1 \%)$ of the UPEC were ESBL- producing strains with concomitant multiple antibiotic resistance profiles. Isolates that produced ESBL-enzymes showed high rate of resistance to the extended spectrum $\beta$-lactam and other classes of antibiotics as well. There was a significant statistical difference in the incidence of resistance between ESBL- and non- ESBL- producing E. coli isolates in Ondo and Ekiti States $(\mathrm{P}<0.05)($ Table 1$)$.

Each of the ESBL producers was resistant to more than one class of antibiotic. The ESBL-producing UPEC $(52.2 \%)$ were resistant to all the six classes of antibiotics tested, $26.1 \%$ to five, $15.9 \%$ to four, and $5.8 \%$ to three classes (Table2).

Figure 1 shows the percentage rate of transfer of resistance phenotypes to the transconjugants. Extended spectrum $\beta$-lactamase enzyme and other antibiotic resistance phenotypes were transferred to non-ESBL- producing $E$. coli, Salmonella sp., Shigella sp., Proteus vulgaris and Klebsiella sp. recipients. Consequently, resistance to other antibiotics was also transferred in the same trend, augmentin, cefotaxime and ceftazidime were $100 \%$ transferred to the transconjugants, followed by amoxicillin $(98.0 \%)$, tetracycline $(94.0 \%)$ and cotrimoxazole $(90.0 \%)$. However, pefloxacin, ciprofloxacin, ofloxacin and nalidixic acid resistance traits were not transferred (Figure 1).

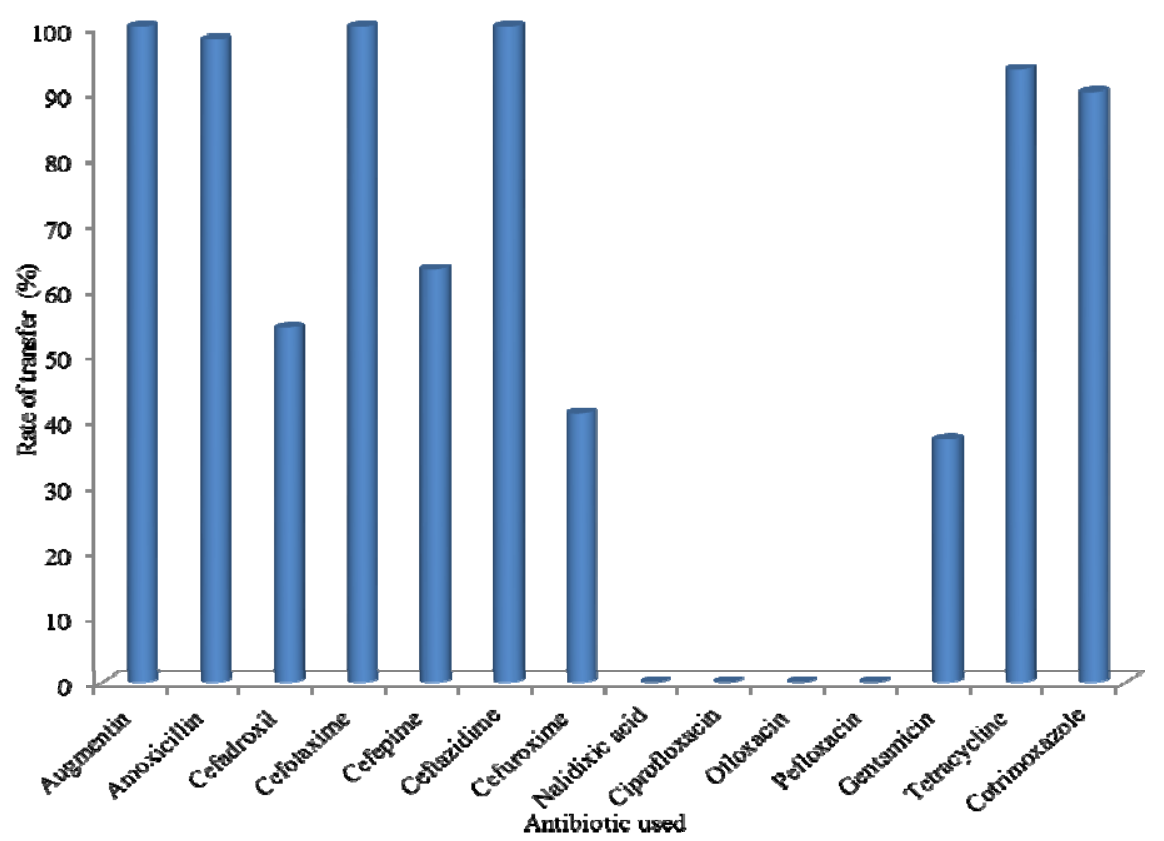

Figure 1. Rate of transfer of resistance phenotypes to the transconjugants (\%)
AUG $=$ Augmentin, $A M X=$ Amoxicillin, $C F R=$ Cefadroxil,
$\mathrm{CAZ}=$ Ceftazidime, $\mathrm{CXM}=$ Cefuroxime, $\mathrm{NAL}=$ NalidixicAcid,
$\mathrm{CTX}=$ Cefotaxime,
$\mathrm{FEP}=$ Cefepime, PFX=Pefloxacin, GEN=Gentamicin, TET $=$ Tetracycline,
$\mathrm{CPX}=$ Ciprofloxacin, $\mathrm{COT}=$ Cotrimoxazole.
$\mathrm{OFL}=$ Ofloxacin, 
Molecular weights of plasmid DNA in the representative MAR -UPEC isolates are presented in table 4 and the gel electrophoresis of the amplified plasmid DNA is shown in Figure 2. Large plasmid size of molecular weights ranging from 23.13- 33.04 $\mathrm{kb}$ were harboured by the selected MAR isolates, and $62.5 \%$ of the isolates were ESBL- producing strains. Some of the non- $\beta$-lactam antibiotic resistant isolates had same plasmid DNA size as those of ESBL-producing UPEC (Table 3).

Table 3. The molecular weight of plasmid DNA in the representative MAR uropathogenic E. coli in pregnant women with UTIs in Ondo and Ekiti States

\begin{tabular}{lll}
\hline $\begin{array}{l}\text { Isolate } \\
\text { code }\end{array}$ & Antibiotics to which isolates were resistant & $\begin{array}{l}\text { Plasmid } \\
\text { (Estimated) } \\
\text { Mol. Wt. [kb] }\end{array}$ \\
\hline EKNG028 & AUG, AMX, AMP, CRO, CFR, CTX, CAZ, CXM, GEN, NIT, TET, COT & 25.70 \\
EKNG114 & AUG, AMX, AMP, CRO, CFR, CTX, FEP, CMX, GEN, NIT, TET, COT & 25.70 \\
ODNG051 & AUG, AMX, CRO, CFR, CAZ, CXM, GEN, NIT, TET, COT & 25.70 \\
ODNG172 & AUG, AMX, AMP, CFR, FEP, CAZ, CXM, GEN, NIT, TET, COT & 25.70 \\
EKNG099 & AUG, AMP, CRO, CFR, FEP, CAZ, CXM, NIT, TET, COT & 25.70 \\
EKNG004 & AUG, AMX, AMP, CRO, CRO, CFR, CTX, FEP, CAZ, CXM, GEN, TET, COT & 25.70 \\
EKNG060 & AUG, AMX, AMP, CRO, CFR, CTX, FEP, CAZ, CXM, GEN, NIT, TET, COT & 25.70 \\
ODNG124 & AUG, AMX, AMP, CRO, CFR, CTX, CAZ, CXM, GEN, NIT, COT & 25.70 \\
ODNG059 & AUG, AMX, AMP, CRO, CFR, CTX, FEP, CAZ, CXM, GEN, NIT, TET, COT & 33.04 \\
0DNG024 & AUG, AMX, AMP, CRO, CFR, CTX, CAZ, CXM, GEN, NIT, TET, COT & 33.04 \\
EKNG007 & AUG, AMX, AMP, CRO, CFR, CTX, FEP, CAZ, CXM, GEN, NIT, TET, COT & 33.04 \\
EKNG080 & AUG, AMX, AMP, CRO, CFR, CTX, CAZ, CXM, GEN, NIT, TET, COT & 33.04 \\
ODNG021 & AUG, AMX, AMP, CRO, CFR, CTX, CAZ, CXM, GEN, NIT, TET, COT & 23.13 \\
EKNG022 & AUG, AMP, CRO, CFR, CTX, CAZ, CXM, GEN, NIT, TET, COT & 23.13 \\
\hline
\end{tabular}

$\mathrm{EKNG}=$ Isolates from Ekiti State, Nigeria; $\mathrm{ODNG}=$ Isolates from Ondo State, Nigeria.

$\mathrm{AUG}=$ Augmentin $\quad \mathrm{AMX}=$ Amoxicillin $\quad \mathrm{AMP}=$ Ampicillin $\quad \mathrm{CRO}=$ Ceftriaxone $\quad \mathrm{CFR}=$ Cefadroxil CTX $=$ Cefotaxime $\quad \mathrm{FEP}=$ Cefepime $\quad \mathrm{CAZ}=$ Ceftazidime $\quad \mathrm{CXM}=$ Cefuroxime $\quad$ GEN $=$ Gentamicin NIT $=$ Nitrofurantoin $\mathrm{TET}=$ Tetracycline $\quad \mathrm{COT}=$ Cotrimoxazole $\quad \mathrm{AMC}=$ Amoxicillin/Clavulanic Acid

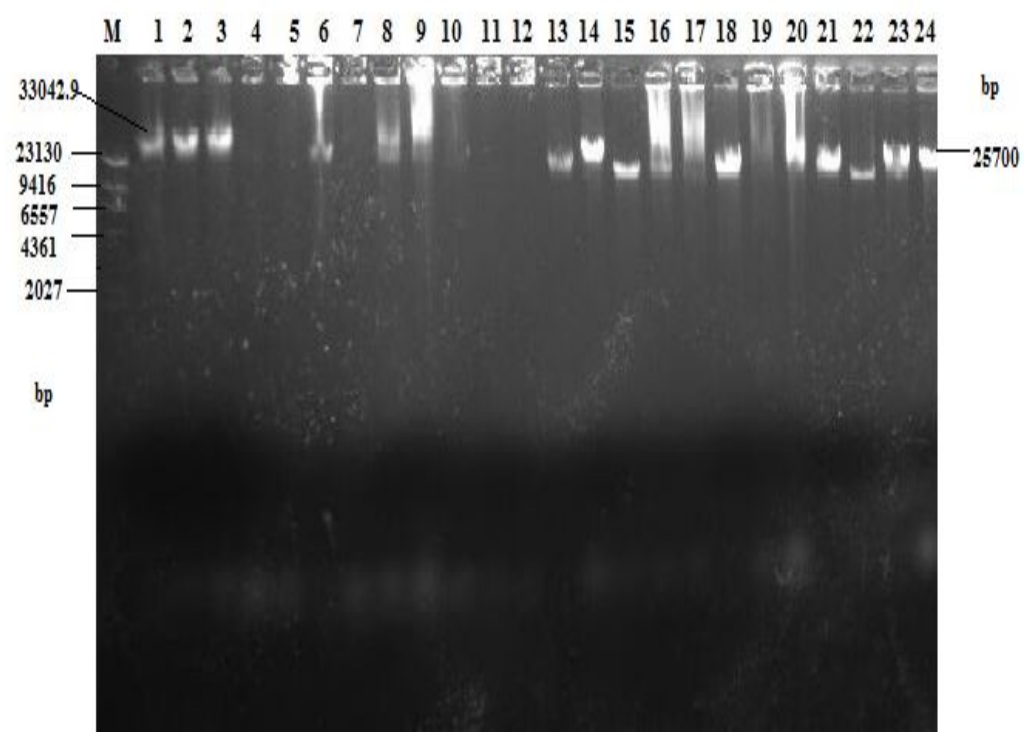

Figure 2. Gel electrophoresis of the amplified plasmid DNA of selected multiple antibiotic resistant uropathogenic E. coli in Ondo and Ekiti Sates

Lane M: DNA marker, Lanes 1-24: the test isolates. 


\section{Discussion}

Present study reveals $26.1 \%$ prevalence of ESBL-enzyme production among UPEC in symptomatic UTIs pregnant women in Ondo and Ekiti States, Nigeria. This contradicts the earlier reports of $75 \%$ by Padmavathy et al. (2014), $52.4 \%$ by Yusuf et al. (2005), 52.4\% by Iroha et al. (2008), and 37.3\% by Aibinu et al. (2003) on prevalence of ESBL enzymes detected in E. coli from UTI patients in the East, South and Northern Nigeria, respectively. Prevalence of ESBL-producing UPEC in this study is higher than reports from other countries and other parts of Nigeria. For instance, in Cameroun, Gangoue-Pieboji (2005) reported 12.0\% prevalence of E. coli with ESBL, El-Khizzi and Bakheshwain (2006) obtained 15.8\% prevalence in Riyadh, Saudi Arabia and Yushau et al. (2007) reported 9.3\% prevalence in Kano, Nigeria. In general, prevalence of ESBLs in E. coli in UTIs cases varies from country to country and from health institution to another (Iroha et al., 2010). The Pan European Antimicrobial Resistance Using Local Surveillance (PEARIS) study between (2001- 2002) showed that, the percentage of ESBL producer among E. coli in UTIs cases was 5.8\% for all the study sites (Bouchillon et al., 2004). In Egypt, a high rate of $38.5 \%$ was observed, $27.4 \%$ were reported from Greece, $2.0 \%$ from the Netherlands and $2.6 \%$ in Germany. In Japan, Korea and Hong Kong, the percentage of ESBL production among E. coli was also low (Ho et al., 2000).

In South and Eastern Nigeria, prevalence of ESBL among E. coli isolated from pregnant patients from 2003-2007 was very high (52.4\%) (Aibinu et al., 2003; Iroha et al., 2008) and is at variance with the findings of the present study. This may likely due to geographical location and antimicrobial usage. The implication of ESBL-producing UPEC in pregnant women may include prolonged stay in the hospital, cost, treatment failure and relapsed cases. A number of risk factors of acquiring ESBL-producing bacteria have been identified in hospitalized patients, most of which also apply to other multi-resistant Gram-negative bacilli. These risk factors include: prolonged hospital stay; prior hospitalization; previous use of $3 \mathrm{GCs}$, aminoglycosides and quinolones; presence of medical devices such as urinary catheters and mechanical ventilation (Rooney et al., 2009). In the case of community acquired ESBL infections, older age, female gender, recurrent UTIs/prior invasive procedures (e.g. catheterization), known faecal carriage, contact with healthcare facilities/residents in care homes and previous antimicrobial treatment are the risk factors (Moor et al., 2008). Transfer of ESBL enzyme and other antibiotic resistance phenotypes in some of the isolates is plasmid-linked. This may be due to the fact that the ESBL genes were located on transposable element or integron thus resulting in transfer function (Akortha et al., 2011). Inter-generic transfer rate in this study is lower than intra species transfer rate. This has been linked to fertility inhibition, incompatibility, inability to synthesize adhesion or narrow host range (Akortha, 2009). Transmission in the community is probably quite complicated. Individuals in long-term care homes where high carriage rates of CTX-M producing enterobacteriaceae have been observed may spread strains (Rooney et al., 2009) to other noncare-home residents. The evidence of a significant spread amongst household contacts has been presented in a Spanish study which showed that $70 \%$ of index cases of patients with ESBL-producing strains causing UTI in the community had positive contacts with $16.7 \%$ of their household members. The finding of this study explains co-selection of resistance as resistance to other non- $\beta$-lactam antibiotics is located on the same plasmid as ESBL factor.

The presence of plasmid-mediated ESBL resistance among the isolates in the present study is an evidence of its transfer capability of ESBL and other resistance phenotypes between its species and other genera. This implies that under favourable condition, horizontal gene transfer of resistance plasmid by conjugation could occur in vivo (Yah et al., 2008). This indicates that plasmid carrying ESBL gene in one bacterium can spread rapidly to members of the same or organisms of different species in the same or different individual. Greater percentage of UPEC in the study area MAR capable of transferring ESBL enzymes and other resistance phenotypes.

\section{Conclusion}

In conclusion, antibiotic resistance remains one of the nature's never ending process whereby organisms develop tolerance to new environmental condition. The development and spread of ESBL- producing UPEC and horizontal transfer of resistance in the study is of great concern especially in therapeutic management of UPEC-induced urinary tract infections.

\section{Acknowledgements}

Authors acknowledge the Chief Medical Director and the Laboratory Scientists of the various hospitals selected for the study.

\section{References}

Aibinu, I. E., Ohagbulam, V. C., Adenipekun, E. A., Ogunsola, F. T., Odugbemi, T. O., \& Mee, B. J. (2003). Extended-spectrum beta-lactamase enzymes in clinical isolates of Enterobacter species from Lagos, Nigeria. J Clin Microbiol, 41(5), 2197-2200. http://dx.doi.org/10.1128/JCM.41.5.2197-2200.2003 
Akortha, E. E., Filgona, J. (2009). Transfer of gentamicin resistance genes among enterobacteriaeceae isolated from the outpatients with urinary tract infections attending 3 hospitals in Mubi, Adamawa State. Sci Resear Essay, 4(8), 745-752. Retrieved from http://www.academicjournals.org/SRE.

Akortha, E. E., Aluyi, H. A. S., Enerrijiofi, K. E. (2011). Transfer of amoxicillin resistance gene among bacterial isolates from sputum of pneumonia patients attending the University of Benin Teaching Hospital, Benin City, Nigeria. Shiraz E-Medical J, 12(4), 1-11. http://semj.sums.ac.ir/vol12/apr2011/89048.htm.

Bloomberg, B., Jureen, R., Manji, K. P, Tamim, B. S., Mwakagile, D. S. M., Urassa, W. K., Fataki, M., Msangi, V. et al. (2005). High rate of fatal cases of pediatric septicemia caused by Gram-negative bacteria with extended-spectrum beta-lactamases in Dar es Salaam, Tanzania. J Clin Microbiol, 43, 745-749. http://dx.doi.org/10.1186/1471-2334-7-43.

Bouchillon, S. K., Jonson, B. M., Hoban, D. J., Johnson, J. L., Dowzicky, M. J., Wu, D. H., Visalli, M. A., Bradford, A. (2004). Determining incidence of extended spectrum $\beta$-lactamase producing Enterobacteriaceae, vancomycin-resistant Enterococcus faecium and methicillin-resistant Staphylococcus aureus in 38 centers from 17 countries: the PEARLS Study 2001-2002. Intern $J$ Antimicro Agents, 24, 119-124. http://dx.doi.org/10.1016/j.ijantimicag.2004.01.010.

Clinical and Laboratory Standards Institute (CLSI) (2012). Performance standards for antimicrobial susceptibility testing. 22nd informational supplement M100-S22. Wayne, PA.

El-Khizzi, N. A. and Bakheshwain, S. M. (2006). Prevalence of extended-spectrum beta-lactamases among Enterobacteriaceae isolated from blood culture in a tertiary care hospital. Saudi Medical J, 27(1), 37-40.

Fang, H., Ferda, A., Göran, H., Dornbusch, K. (2008). Molecular epidemiology of extended-spectrum $\beta$-lactamases among Escherichia coli Isolates collected in a Swedish hospital and its associated health care facilities from 2001 to 2006, J Clin Microbiol, 46(2), 707-712. http://dx.doi.org/10.1128/JCM.01943-07

Gangoue-Pieboji, J. (2005). Extended spectrum-beta-lactamase-producing enterobacteriaceae in Yaounde, Cameroon. J Clin Microbiol, 43, 3273 - 3277. http://dx.doi.org/10.1128/JCM.43.7.3273-3277.2005.

Ho, P. L., Tsang, D. N. C., Que, T. L., Ho, M., Yuen, K. Y. (2000). Comparison of screening methods for detection of extended-spectrum $\beta$-lactamase and their prevalence among Escherichia coli and Klebsiella sp. in Hong Kong. Acta Pathol, Microbiol et Immunol Scandinavica, 108, 237-240. http://dx.doi.org/10.1093/jac/dki010.

Holt, J. G., Krieg, N. R., Sneath, P. H., Staley, J. T., Williams, T., Hensyl, W. R. (1994). Bergy's manual of determination bacteriological. $9^{\text {th }}$ ed., Williams and Wilkins, Baltimore, Meryland.

Iroha, I. R., Adikwu, M. U., Amadi, E. S., Aibinu, I., Esimone, C. O. (2008). Characterization of extended spectrum $\beta$-lactamase producing E. coli from secondary and tertiary hospital in South Eastern Nigeria. Resear J Microbiol, 3, 514-519. http://dx.doi.org/10.3923/jm.2008.514.519.

Iroha, I. R., Adikwu, M. U., Esimone, C. O., Aibinu, I., Amadi, E. S. (2009). Extended spectrum beta-lactamase (ESBL) in E. coli isolated from a tertiary hospital in Enugu State, Nigeria. Pakistan J Medicin Sci, 25, 279-288.

Iroha, I. R., Amadi, E. S., Nwazo, A. C., Ejike-ugwu, P. C. (2010). Detection of plasmid borne ESBLs from blood and urine isolates of Gram negative bacteria from University Teaching Hospital in Nigeria. Current Resear Bacter, 3, 77-83. http://dx.doi.org/10.3923/crb.2010.77.83.

Kraft, R., Tardiff, J., Krauter, K. S., Leinwand, L. A. (1988). Using mini-prep plasmid DNA for sequencing double stranded template with sequences. Biotechnol, 6, 544.

Lech, K. and Brent, R. (1987). Mini-prep of plasmid DNA. P. 1.6.1. 1.6.4. In Ausubel, F. M., Brent, R., Kingston, R. E., Moore, D. D., Seidman, J. G., Smith, J. A. (Eds). Current Protocol in Molecular Biology. John Wiley and Sons, NY.

Livermore, D. M., Canton, R., Gniadkowski, M., Nordmann, P., Rossolini, G. M., Arlet, G., Ayala Coque, T. M. et al. (2007). Changing the face of ESBLs in Europe. J Antimicrob Chemoth, 59(2), 165-174. DOI:10.1093/jac/dk1483.

Maina, D., Makau, P., Nyerere, A. and Revathi, G. (2013). Antimicrobial resistance patterns in extended-spectrum $\beta$-lactamase producing Escherichia coli and Klebsiella pneumoniae isolates in a private tertiary hospital, Kenya. Microbiology Discovery, 1(5), 1-4. http://dx.doi.org/10.7243/2052-6180-1-5.

Moor, C. T., Roberts, S. A., Simmons, G., Briggs, S., Morris, A. J., Smith, J., Heffernan, H. (2008). Extended-spectrum beta-lactamase producing enterobacteria: factors associated with infection in the 
community setting, Auckland, New Zealand. $J$ Hospital Infect, 68, 355-362. http://dx.doi.org/10.1016/j.jhin.2008.02.003.

Padmavathy, K., Krishnan, P., Rajasekaran, S. (2014). Fluoroquinolone resistance among CTX-M producing uropathogenic Escherichia coli from HIV and non-HIV patients in South India. BMC Infect Dis, 14 (3), 63. http://dx.doi.org/10.1186/1471-2334-14-S3-P63.

Paterson, D. L and Bonomo, R. A. (2005). Extended-spectrum $\beta$-lactamases: a clinical update. Clin Microbiol Rev, 18, 657-86. http://dx.doi.org/10.1128/CMR.18.4.657-686.2005.

Pitout, J. D. D., Daniel, B. G., Lorraine, C., Kevin, B. L. (2009). Molecular characteristics of extended-spectrum- $\beta$-lactamase-producing Escherichia coli isolates causing bacteremia in the Calgary health region from 2000 to 2007: Emergence of clone ST131 as a cause of community-acquired infections. Antimicr Agents Chemotherap, 53(7), 2846-2851. http://dx.doi.org/10.1128/AAC.00247-09.

Pitout, J. D. D., Nordmann, P., Laupland, K. B., Poirel, L. (2005). Emergence of Enterobacteriaceae producing extended-spectrum $\beta$-lactamases (ESBLs) in the community. $J$ Antimicrob Chemother 5; 56: 52-59. http://dx.doi.org/10.1093/jac/dki166.

Ramphal, R. and Ambrose, P. G. (2006). Extended-spectrum beta-lactamases and clinical outcomes: current data. Clin Infect Dis, 42(4): 164-172. http://dx.doi.org/10.1086/500663.

Rodriguez-Bano, J., Navarro, M. D., Romero, L., Muniain, M. A., Perea, E. J., Perez-Cano, R., Hernandez, J. R. and Pascual, A. (2006). Clinical and molecular epidemiology of extended-spectrum beta-lactamase-producing Escherichia coli as a cause of nosocomial infection or colonization: implications for control. Clin Infect Dis, 42, 37-45. http://dx.doi.org/10.1086/498519.

Rooney, P. J., O’Leary, M. C., Loughrey, A. C., McCalmont, M., Smyth, B., Donaghy, P., Badri, M.et al. (2009). Nursing homes as a reservoir of extended-spectrum $\beta$-lactamase (ESBL)-producing ciprofloxacin-resistant Escherichia coli. J Antimicrob Chemother, 64, 635-4. http://dx.doi.org/10.1093/jac/dkp220.

Tham, J., Odenholt, I., Walder, M., Melander, E. and Odenholt, I. (2010). Extended-spectrum beta-lactamase-producing Escherichia coli in patients with travellers' diarrhoea. Scandinavian J Infect Dis, 42, 275-280. http://dx.doi.org/10.2147/IDR.S34941.

Warren, R., Butler, V. N., O'Neill, K., Taylor, J., Ensor, V. and Harvey, P. (2008). Imported chicken meat as a potential source of quinolone-resistant Escherichia coli producing extended-spectrum $\beta$-lactamases in the UK. Antimicrob Chemother, 61(3), 504-508. http://dx.doi.org/10.1093/jac/dkm517.

Yah, S. C., Yusuf, O. E., Eghafona, N. O. (2008). Pattern of antibiotic usage by adult populations in the city of Benin, Nigeria. Scientific Resear Essays, 3(3), 081-085. Retrieved from http://www.academicjournals.org/SRE

Yushau, M., Olonitola, S. O., Aliyu, B. S. (2007). Prevalence of extended - spectrum beta lactamases (ESBLs) among members of the enterobacteriaceae isolates obtained from Mohammed Abdullahi Wase specialist hospital, Kano, Nigeria. Inter J Pure Appl Sci, 1(3), 42-48. http://dx.doi.org/10.4314/bajopas.v4i2.37.

Yusuf, I., Arzai, A. H., Umar, A., Magaji, N., Salisu, N., Tukur, A., Haruna, M., Hamid, K. M. (2011). Prevalence of extended spectrum beta-lactamases (ESBL) producing Escherichia coli and Klebsiella pneumoniae in tuberculosis patients in Kano, Nigeria. Bayero $J$ Pure Appl Sci, 4(2), 182-185. http://dx.doi.org/10.4314/bajopas.v4i2.37

\section{Copyrights}

Copyright for this article is retained by the author(s), with first publication rights granted to the journal.

This is an open-access article distributed under the terms and conditions of the Creative Commons Attribution license (http://creativecommons.org/licenses/by/3.0/). 